\title{
KNOWLEDGE AND HEALTH BEHAVIOURS CONNECTED WITH MELANOMA PREVENTION AMONG PEOPLE LIVING in Poland and Australia
}

\author{
Elżbieta Walewska ${ }^{1 \mathrm{~A}, \mathrm{C}, \mathrm{D}, \mathrm{E}, \mathrm{F}}$, Lucyna Ścisło ${ }^{1 \mathrm{C}, \mathrm{D}, \mathrm{E}}$, Grażyna Puto ${ }^{1 \mathrm{C}, \mathrm{E}}$, Paulina Obrzut ${ }^{2 \mathrm{~A}, \mathrm{~B}, \mathrm{C}}$, Agnieszka Gniadek $^{3 \mathrm{D}, \mathrm{E}, \mathrm{F}}$
}

\author{
'Department of Clinical Nursing, Institute of Nursing and Midwifery, Faculty of Health Sciences, \\ Jagiellonian University Medical College, Krakow, Poland \\ 2Department of Clinical Nursing, postgraduate student at the Faculty of Health Sciences, \\ Jagiellonian University Medical College, Krakow, Poland \\ ${ }^{3}$ Department of Nursing Management and Epidemiological Nursing, Institute of Nursing \\ and Midwifery, Faculty of Health Sciences, Jagiellonian University Medical College, Krakow, \\ Poland

\section{Authors' contribution:} \\ A. Study design/planning • B. Data collection/entry • C. Data analysis/statistics • D. Data \\ interpretation • E. Preparation of manuscript $\bullet$ F. Literature analysis/search $\bullet$ G. Funds collection \\ Address for correspondence: \\ Dr Elżbieta Walewska \\ Department of Clinical Nursing \\ Institute of Nursing and Midwifery \\ Faculty of Health Sciences \\ Jagiellonian University Medical College \\ 25 Kopernika St., 31-501 Krakow, Poland \\ e-mail: elzbieta.walewska@uj.edu.pl \\ SUBMITTED: 13.05 .2020 \\ ACCEPTED: 18.05 .2020 \\ DOI: https://doi.org/10.5114/ppiel.2020.98770
}

\begin{abstract}
Introduction: Melanoma is a malignant skin tumour. Its incidence doubles every 10 years. The sooner it is diagnosed, the better the chances for successful treatment. Therefore, the need has arisen to spread knowledge about early detection of melanoma and its prevention.

Aim of the study: To assess the knowledge and the extent to which skin cancer preventive measures are followed in selected groups of inhabitants of Poland and Australia.

Material and methods: The study was conducted in a group of 267 people, 151 of whom lived in Poland and 116 in Australia. The study was carried out with the application of a diagnostic survey method. The research technique was a survey, and the research tool was a questionnaire designed by the authors. The study findings were examined by means of statistical analysis.

Results: The study showed that although the average level of knowledge is good (46.4\%), the extent to which the rules of melanoma prevention are applied is still unsatisfactory in the majority of population (42.3\%). It was observed that Australian inhabitants had higher scores in both aforementioned cases ( $p<0.001)$; $91.4 \%$ of respondents had at least satisfactory knowledge about melanoma and $78.4 \%$ of them took proper preventive measures, whereas in Poland it was $75.5 \%$ and $41.7 \%$, respectively.

Conclusions: In most cases the respondents have a good level of knowledge, but they do not follow the rules of melanoma prevention. Australians have more knowledge about melanoma, and they are also more likely to take preventive measures.
\end{abstract}

Key words: prevention, melanoma, health behaviours.

\section{INTRODUCTION}

Melanoma is a malignant type of skin cancer originating in neuroectodermal cells known as melanocytes [1]. Melanoma accounts for only $10 \%$ of all cases of malignant skin cancer; however, it causes over $90 \%$ of skin cancer deaths [2, 3]. Statistical data collected over the last decades indicate a worldwide increasing tendency in the incidence rate of malignant skin cancer including melanoma $[4,5]$. It is estimated that in the case the Caucasian race the incidence rate has increased five times over the past three decades [6]. Statistics show that a relatively constant yearly increase of $3 \%$ can be observed for this population starting from 2004 [7]. In Poland melanoma is still diagnosed relatively rarely; the standardised morbidity rate is approx- imately 6.0/100,000 [8]. Nevertheless, following worldwide tendencies, a dynamic increase in melanoma incidence can be observed also in Poland; the yearly number of melanoma diagnoses tripled between 1980 and 2010 [9]. In comparison, in Australia, because of its geographical position and low level of protective skin pigmentation in the white population, the morbidity rate is the highest in the world and reaches 50/100,000 for men, and 37/100,000 for women [10].

An increasing tendency in melanoma incidence gives rise to the necessity for people all over the world to implement proper preventive measures. Melanoma can be prevented, and its early detection allows for appropriate and efficient treatment. It is usually connected with the necessity to undertake certain preventive health behaviours. Melanoma prevention involves 
mainly protection against natural and artificial ultraviolet radiation (UV). Generally available protection against UV radiation consists of wearing sun-protective clothing, wide-brimmed hats, and sunglasses [11, 12]. It also involves application of sunscreen lotions that contain filters blocking UVB and UVA radiation [13-15]. Effective prevention of melanoma and skin cancer means also spreading knowledge about health hazards connected with indoor tanning (tanning salons), which are dangerous especially for teenagers [16, 17]. In 2009 the World Health Organisation classified indoor tanning as a significant cancer risk factor [18]. Since then, between 2009 and 2015, the popularity of indoor tanning among American high school students decreased significantly [19]. Both in Australia and the USA the importance of the issues such as self-examination of one's skin [20], as well as dermoscopy, which can be carried out in specialist clinics, is particularly addressed [21].

In order to raise awareness of the effectiveness of both self-examination and regular medical examination of one's skin by a doctor, educational programmes and preventive actions are introduced for the general population. In 2019 in Poland the seventh edition of the project called "Tydzień Świadomości Czerniaka" took place. Within the programme "Opracowanie koncepcji i założeń merytorycznych programów polityki zdrowotnej planowanych do wdrożenia w procedurze konkursowej" nr POWR.05.01.00-00-0001/15, representatives of the Ministry of Health, National Health Fund and patients' organisation prepared a programme called "ABCDE samokontroli znamion - ogólnopolski program profilaktyki nowotworów skóry - 2017-2023”.

\section{AIM OF THE STUDY}

The objective of the study was to assess the knowledge and the extent to which skin cancer preventive measures are followed in selected groups of inhabitants of Poland and Australia.

\section{MATERIAL AND METHODS}

The study group consisted of 267 people. Most of the respondents lived in Poland - 151 (56\%), and the remaining 116 people lived in Australia (44\%). The respondents were aged between 17 and 62 years.

The study was carried out with the application of a diagnostic survey method. The research technique was a survey, and the research tool was a questionnaire designed by the authors. The study was conducted online by means on an electronic version of the questionnaire, the link to which was posted on several social networking sites and Internet forums. Participation in the study was voluntary and unassisted, and the respondents were ensured full anonymity.

The questionnaire consisted of 30 questions divided into three thematic sections: sociodemo- graphic data - 7 questions; respondents' knowledge - 11 questions; and respondents' prevention behaviours - 12 questions. Two versions of the questionnaire were prepared with identical contents: a Polish and an English one. The need for cultural adaptation of the questionnaire was taken into account.

The section examining respondents' knowledge included questions about the following: melanoma definition, its symptoms, examinations allowing for diagnosis of the problem, cancer prevention rules, melanoma risk factors, and effective treatment. The questions in the section connected with declared prevention behaviours referred to the following: respondents' observations of their nevi, the frequency of examining one's skin, medical check-ups aimed at examining skin changes, seeking information about melanoma, melanoma detection, following the rules of sun protection on sunny days (sunscreen cosmetics, appropriate filters, and protective clothing), visiting tanning salons, as well as knowledge and experience connected with cancer prevention programmes and declared willingness to self-control or have a medical examination of the whole body surface.

In order to assess the total level of respondents' knowledge about melanoma and their declared behaviours connected with its prevention, the respondents' answers to questions included in particular parts of the questionnaire were thoroughly analysed. Every answer was assigned a particular score depending on its rank in relation to others. The respondents could attain a score between 0 and 28 for their responses to questions about their knowledge and between 0 and 26 for their answers to questions connected with prophylactic behaviours.

In order to define the levels of declared health behaviours, the following scale was applied: very good level of health behaviours: $>90 \%$, good level: $75.1-90 \%$, satisfactory level: $60-75 \%$, unsatisfactory level: $<60 \%$ of total possible scores.

The findings obtained in the study were subsequently examined with the application of statistical analysis carried out by means of Microsoft Office Excel 2007 software, and the differences between the obtained data were verified with the application of the $\chi^{2}$ test of independence and Pearson $\chi^{2}$ test. As an assumption the significance level was set at $p=0.05$.

\section{RESULTS \\ Knowledge about melanoma prevention}

After analysis of 267 responses to the questions assessing knowledge about melanoma, the respondents were divided into four groups according to their level of knowledge.

The average score obtained by respondents was 20.9 (74.6\%), which allowed classification of their average level of knowledge about melanoma as satis- 
factory. The results included both very low and very high scores, which is indicative of a large variety of information that particular members of society possess (Tables 1 and 2).

It was proven that there is a statistically significant difference in the level of knowledge about melanoma in the examined population $(p<0.001)$. The highest percentage of this population was found to possess a good level of this knowledge. The group that obtained a satisfactory level of knowledge was nearly half as numerous, and $47(17.61 \%)$ respondents had an unsatisfactory level of knowledge. The smallest group of people possessed a very good level of knowledge about the examined issue. Detailed results obtained by the respondents within the discussed range of knowledge are presented in Table 2.

These results showed a statistically significant difference in respondents' knowledge depending on the country in which they lived $(p<0.001)$. In Austra-

Table 1. Distribution of respondents in the examined group depending on their level of knowledge about melanoma

\begin{tabular}{|c|c|c|c|c|}
\hline Level of knowledge & $n$ & $\%$ & $\chi^{2}$ & $p$-value \\
\hline Very good & 27 & 10.11 & 78.7 & $<0.001^{*}$ \\
\hline Good & 124 & 46.44 & & \\
\hline Satisfactory & 69 & 25.84 & & \\
\hline Unsatisfactory & 47 & 17.61 & & \\
\hline Total & 267 & 100 & & \\
\hline
\end{tabular}

lia the total percentage of people with very good or good knowledge was higher than in Poland. However, statistically the largest number of respondents from both countries had a good level of knowledge. Detailed data are presented in Table 3.

\section{Health behaviours connected with melanoma prevention}

After an analysis of 267 responses to the questions that assessed the level of declared preventive behaviours, the respondents were divided into four groups depending on their level of these behaviours.

The average score obtained by respondents was 16.1, which was interpreted as a satisfactory level of preventive behaviours. A wide score range could be observed, which reflected differences in respondents' behaviours. The findings showed statistically significant differences in the extent to which respondents followed the rules of prevention recommended for this form of malignant skin cancer $(p<0.001)$. The respondents were most likely to present an unsatisfactory level of practical behaviours connected with melanoma preventive measures and early detection of this form of skin cancer (Table 4).

Detailed results are presented in Table 5.

The level of applying melanoma prevention rules differs in the examined population, ranging from unsatisfactory to very good. A statistical analysis of the responses provided in the study shows that a vast majority of respondents fail to apply preventive measures in practice to a satisfactory extent.

Table 2. Detailed results of the assessment of respondents' level of knowledge about melanoma

\begin{tabular}{|c|c|c|c|c|c|c|c|}
\hline \multirow{2}{*}{$\begin{array}{l}\text { Level of } \\
\text { knowledge }\end{array}$} & \multirow[t]{2}{*}{ Score range } & \multicolumn{2}{|c|}{ Obtained score } & \multirow{2}{*}{$\begin{array}{c}\text { Average } \\
\text { value }\end{array}$} & \multirow[t]{2}{*}{ Mode } & \multirow[t]{2}{*}{ SD } & \multirow{2}{*}{$\begin{array}{c}\text { Confidence } \\
\text { interval }\end{array}$} \\
\hline & & $\min$ & $\max$ & & & & \\
\hline Very good & 25.3-28.0 & 25.5 & 27.0 & 25.7 & 25.5 & 0.45 & 0.17 \\
\hline Good & $21.1-25.2$ & 21.5 & 25.0 & 23.5 & 24.5 & 1.0 & 0.18 \\
\hline Satisfactory & $16.8-21.0$ & 17.0 & 21.0 & 19.3 & 20.5 & 1.4 & 0.33 \\
\hline Unsatisfactory & $0-16.8$ & 3.5 & 16.5 & 13.8 & 16.5 & 2.9 & 0.83 \\
\hline
\end{tabular}

Table 3. Correlation between the country of residence and the level of knowledge and application of rules connected with melanoma prevention

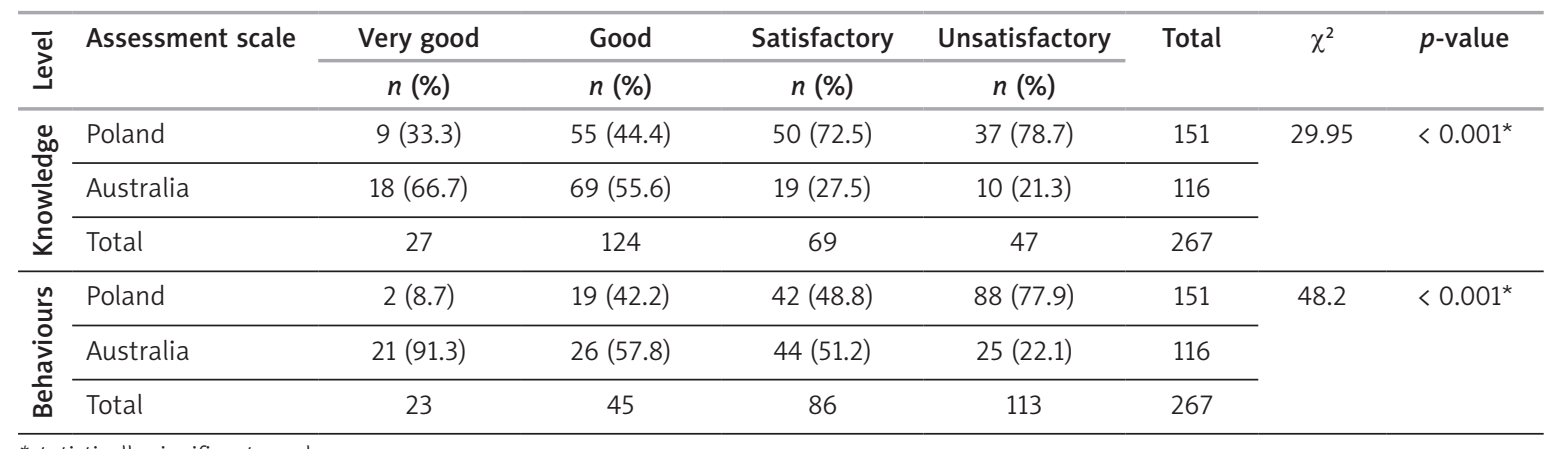

*statistically significant $p$-value 
Afterwards, the groups from both examined countries were compared, and similar results were obtained as far as preventive behaviours were concerned $(p<0.001)$ (Table 3). The level of health behaviours was usually unsatisfactory in the case of Polish people, whereas Australians presented a satisfactory level of these behaviours. As far as preventive behaviours were concerned, Australians were definitely more likely to use proper prevention.

There are noticeable differences in respondents' knowledge and their application of rules of melanoma prevention depending on the country in which they live. The comparison of Polish and Australian inhabitants shows that better results were obtained by the latter.

Table 6 shows a correlation between respondents' knowledge and the level of following melanoma prevention rules. People with unsatisfactory or only satisfactory level of knowledge usually fail to apply preventive measures to a satisfactory extent. In the other groups this correlation is not so obvious; for example, in a group of people with a good level of knowledge, the extent to which they apply proper prevention rules is usually only satisfactory.

The level of knowledge is correlated with the level of behaviours aimed at melanoma prevention $(p<0.001)$. It is observed especially in the case of respondents with an unsatisfactory level of knowledge, because not having theoretical rudiments, they do not present proper behaviours on a very good level. On the other hand, the study findings show that the knowledge of prevention rules is not always applied in practice.

\section{DISCUSSION}

Melanoma is a form of cancer that can be prevented to a large extent thanks to the application of appropriate knowledge in everyday activities aimed at skin cancer prevention. However, the level of knowledge and the application of melanoma prevention rules by the general population are still insufficient to prevent or to detect a malignancy at its early stage. Therefore, an urgent need arises to launch health promotion campaigns for the general population, including not only primary but also secondary melanoma prevention [22]. In the authors' own studies conducted in a group of 267 people living either in Poland (56\%) or Australia (44\%), statistically significant differences were observed as far as knowledge and application of rules connected with melanoma prevention are concerned, and these differences depended on the respondents' country of residence. It was observed that Australians obtained higher scores in both cases; $91.4 \%$ of them possessed at least satisfactory level of

Table 4. Score distribution in the examined group of respondents depending on the level of their declared behaviours connected with melanoma prevention

\begin{tabular}{lcccc}
\hline Level of health behaviours & $n$ & $\chi^{2}$ & $p$-value \\
\hline Very good & 23 & 73.4 & $<0.001^{*}$ \\
\cline { 1 - 2 } Good & & \\
\hline Satisfactory & 45 & & \\
\hline Unsatisfactory & 113 & & \\
\hline *statistically significant $p$-value & & &
\end{tabular}

Table 5. Detailed results of the assessment of the level of declared behaviours connected with melanoma prevention

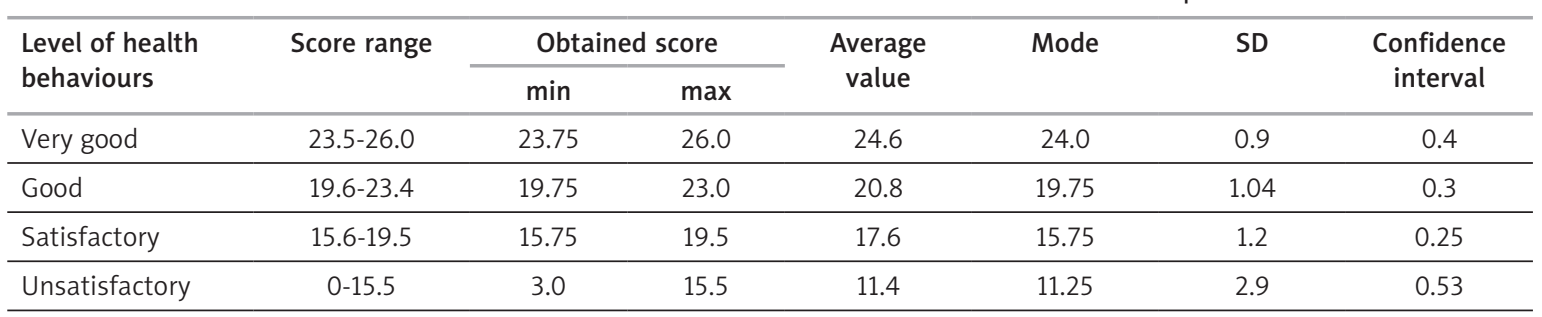

Table 6. Correlation between the level of knowledge and the level of preventive behaviours connected with melanoma, $N=267$

\begin{tabular}{|c|c|c|c|c|c|c|c|}
\hline \multirow{2}{*}{$\begin{array}{l}\text { Level of } \\
\text { knowledge }\end{array}$} & \multicolumn{5}{|c|}{ Level of preventive behaviours connected with melanoma } & \multirow[t]{2}{*}{$\chi^{2}$} & \multirow[t]{2}{*}{$p$-value } \\
\hline & $n(\%)$ & $n(\%)$ & $n(\%)$ & $n(\%)$ & & & \\
\hline Very good & $9(39.1 \%)$ & $6(13.3 \%)$ & $9(10.5 \%)$ & $3(2.7 \%)$ & 27 & 62.1 & $<0.001^{\star}$ \\
\hline Good & $12(52.2 \%)$ & 30 (66.7\%) & 45 (53.3\%) & 37 (32.7\%) & 124 & & \\
\hline Unsatisfactory & $0(0 \%)$ & $4(8.9 \%)$ & $10(11.6 \%)$ & $33(29.2 \%)$ & 47 & & \\
\hline Total & 23 & 45 & 86 & 113 & 267 & & \\
\hline
\end{tabular}

*statistically significant $p$-value 
knowledge and $78.4 \%$ declared taking proper preventive measures, whereas in the case of Polish respondents it was $75.5 \%$ and $41.7 \%$, respectively. Higher scores obtained by Australian people may result from the fact that they live in the country with the highest melanoma incidence rate [10]. Moreover, in Australia the number of educational programmes aimed at melanoma prevention is the highest, and elements of melanoma prevention were introduced into school curriculums all over the country [23].

The study showed that as many as $46.4 \%$ of respondents possess a good level of theoretical knowledge about melanoma prevention; however, most of the examined population (42.3\% of respondents) presented an unsatisfactory level of undertaken activities aimed at early detection of malignancies, including photoprotection in its broad sense. Similar results were obtained in a study conducted at the beginning of 2016 in a group of nursing students at one of the universities in Lublin. These results showed that despite a high level of knowledge about cancer prevention (which was obtained by $92 \%$ of respondents), a higher percentage of them follow proper health behaviours only "from time to time" [24]. Thus, it was proven that higher knowledge is not always accompanied by proper decisions in everyday activities, which is similar to the results obtained in the studies carried out in Romania [22]. Therefore, it should be concluded that a low level of preventive behaviours in the general population is not caused by knowledge deficit but rather by a lack of confidence in these behaviours and motivation for applying them in practice.

Summing up, due to an increasing melanoma incidence rate all over the world, it is undeniably necessary to develop and implement social programmes aimed at prevention of this type of cancer. As can be concluded from this study, such programmes should focus not only on spreading theoretical knowledge, but most of all on encouraging people to follow preventive rules and motivating them to self-check their skin as well as to have regular medical examinations in doctor's surgeries.

\section{CONCLUSIONS}

Respondents' knowledge about melanoma prevention and detection is varied in the examined population; however, it remains on a good level. As far as the declaration of following the melanoma prevention rules is concerned, the most numerous was the group of respondents who obtained unsatisfactory scores.

There are considerable differences in people's knowledge and their following of the rules of melanoma prevention, depending on the country of their origin. Australian respondents' knowledge is consider- ably greater, and they are better at following the rules of melanoma prevention than Polish respondents.

A considerable knowledge deficit as far as melanoma is concerned and insufficient prevention measures indicate a serious need for education in this area as well as the development and implementation of appropriate social programmes of melanoma prevention.

\section{Disclosure}

The authors declare no conflict of interest.

\section{References}

1. Drobek HH, Bergler-Czop BS, Miziołek B. Od chemioterapii do onkowirusów - nowoczesne metody leczenia czerniaka przerzutowego. Prz Dermatol 2017; 104: 396-410.

2. Jemal A, Bray F, Center MM, et al. Global cancer statistics. CA Cancer J Clin 2011; 61: 69-90.

3. Touboul C. Methodology of the EDIFICE melanoma survey. J Eur Acad Dermatol Venereol 2015; 29 (Suppl 2): 2-5.

4. Forsea AM, Del Marmol V, de Vries E, et al. Melanoma incidence and mortality in Europe: new estimates, persistent disparities. Br J Dermatol 2012; 167: 1124-1130.

5. Rosenthal A, Stoddard M, Chipps L, et al. Skin cancer prevention: a review of current topical options complementary to sunscreens. J Eur Acad Dermatol Venereol 2019; 33: 1261-1267.

6. Pacholczyk M, Czernicki J, Ferenc T. Wpływ słonecznego promieniowania ultrafioletowego (UV) na powstawanie raków skóry. Med Pr 2016; 67: 255-266.

7. Nawrocka A, Owczarek W. Zasady diagnostyki u pacjentów z podejrzeniem nowotworu skóry. Chir Dypl 2014; 1-2: 7-21.

8. Didkowska J, Wojciechowska U, Czaderny K, et al. Nowotwory złośliwe w Polsce w 2017 r. Krajowy Rejestr Nowotworów, Zakład Epidemiologii i Prewencji Nowotworów MZ Warszawa 2019.

9. Rutkowski P, Wysocki PJ, Nasierowska-Guttmejer A, et al. Czerniaki skóry. Onkologia w Praktyce Klinicznej - Edukacja 2019; 5: 1-20.

10. Schadendorf D, van Akkooi ACJ, Berking C, et al. Melanoma. Lancet 2018; 392: 971-984.

11. Olsen CM, Wilson LF, Green AC, et al. How many melanomas might be prevented if more people applied sunscreen regularly? Br J Dermatol 2018; 178: 140-147.

12. Vasicek BE, Szpunar SM, Manz-Dulac LA. Patient knowledge of sunscreen guidelines and frequency of physician counseling: a cross-sectional study. J Clin Aesthet Dermatol 2018; 11: $35-40$.

13. Kamenisch Y, Baban TSA, Schuller W, et al. UVA-irradiation induces melanoma invasion via the enhanced warburg effec. J Invest Dermatol 2016; 136: 1866-1875.

14. Khan AQ, Travers JB, Kemp MG. Roles of UVA radiation and DNA damage responses in melanoma pathogenesis. Environ Mol Mutagen 2018; 59: 438-460.

15. Watts CG, Drummond M, Goumas C, et al. Sunscreen use and melanoma risk among young Australian adults. JAMA Dermatol 2018; 154: 1001-1009.

16. Boniol M, Autier P, Boyle P, et al. Cutaneous melanoma attributable to sunbed use: systematic review and meta-analysis. BMJ 2012; 345: Article e4757.

17. Dawes SM, Tsai S, Gittleman H, et al. Racial disparities in melanoma survival. J Am Acad Dermatol 2016; 75: 983-991. 
18. Ghissassi FEl, Baan R, Straif K, et al. A review of human carcinogens - Part D: radiation. Lancet Oncol 2009; 10: 751-752.

19. Guy Jr GP, Berkowitz Z, Everett Jones S, et al. Prevalence of indoor tanning and association with sunburn among youth in the United States. JAMA Dermatol 2017; 153: 387-390.

20. Watts CG, Cust AE, Menzies SW, et al. Cost-effectiveness of skin surveillance through a specialized clinic for patients at high risk of melanoma. J Clin Oncol 2017; 35: 63-71.

21. Dinnes J, Deeks JJ, Chuchu N, et al. Dermoscopy with and without visual inspection, for diagnosing melanoma in adults. Cochrane Database Syst Rev 2018; 12: CD011902.

22. Fechete O, Ungureanu L, Șenilă S, et al. Risk factors for melanoma and skin health behaviour: An analysis on Romanian melanoma patients. Oncol Lett 2018; 17: 4139-4144.

23. Żelasko A. Wiedza studentów kierunków medycznych na temat profilaktyki, rozpoznawania i leczenia czerniaka skóry. Probl Pielęg 2014; 22: 216-222.

24. Gujska D, Gutek A, Gajewska N, et al. Zachowania zdrowotne studentów pielęgniarstwa w zakresie profilaktyki chorób nowotworowych. J Educ Health Sport 2016; 6: 107-120. 